\title{
河川増水時における鉄道橋脚の固有振動数の 特定方法の提案
}

\author{
佐溝 昌彦 1 渡邉 $\quad$ 諭 2 - 淵脇 晃 $^{3} \cdot$ 杉山 友康 4 -岡田 勝也 5 \\ 1正会員 （財）鉄道総合技術研究所 防災技術研究部 地盤防災研究室 \\ （干185-8540 東京都国分寺市光町2-8-38） \\ E-mail:samizo@rtri.or.jp \\ 2正会員 (財) 鉄道総合技術研究所防災技術研究部 地盤防災研究室 \\ （干185-8540 東京都国分寺市光町2-8-38） \\ 3正会員 九州旅客鉄道株式会社 施設部工事課（ ( $812-8566$ 福岡県福岡市博多区博多駅前3-25-21） \\ 4フェロー （財）鉄道総合技術研究所 防災技術研究部（†185-8540 東京都国分寺市光町2-8-38） \\ 5フェロー 国士舘大学＼cjkstart理工学部（干154-8515 東京都世田谷区世田谷4-28-1）
}

\begin{abstract}
鉄道橋梁では河川増水時に橋脚基礎周辺の河床が洗掘されて基礎構造物としての安定性が低下し，橋脚 が傾斜・転倒することがある。こうした災害から旅客や列車を守るため，防護工の施工や橋梁改築のよう なハード対策に加えて，ソフト対策として河川水位に応じて列車運行を制限する運転規制を行っている. 本研究では，その運転規制の実施の可否判断を支援するため，橋脚天端での微動計測によって基礎の健全 性を表す指標である橋脚の固有振動数を求めることを目的としている。ここでは，水理模型実験による流 水中の橋脚の微動計測と実橋梁における河川増水時の微動計測から, 橋脚の固有振動数を精度良くかつ讯 速に把握することができるアルゴリズムを提案し，それを他の橋梁に適用してその有効性を示した。
\end{abstract}

Key Words : microtremor, scour, pier, spread foundation, train operation control, natural frequency

\section{1. はじめに}

わが国の鉄道網は1872年新橋・横浜間に初めて開業し て以来，昭和初期までに急速に整備が進んだ．その当時 に建造された古い構造形式の建造物は現在でも数多く存 在し供用されている. その中でも直接基礎形式の橋梁は, 比較的支間が短く基礎が浅い位置にあるため，橋脚基礎 部の洗掘や河床低下の影響を受けやすく，これまでも洗 掘による橋梁被害が数多く発生している. 特に河川増水 時には，橋脚の基礎周辺地盤が洗掘を受け，基礎の安定 性が短時間のうちに低下し，橋脚が傾斜・転倒するとい う災害形態が多く発生してきた，さらに，近年局地的な 豪雨が多発する傾向とも相まって，2003年8月台風10号 による日高線被害, 2004年7月の新潟・福島豪雨や福井 豪雨による信越線や越美北線被害，2004年10月台風23号 による高山線被害，2005年9月台風14号による高千穂鉄 道被害など，毎年といってよいほど鉄道橋梁が被害を受 けている.

このような河川増水時の橋梁災害から旅客および列車 の安全を確保するため，八ード対策として各種の防護工 を橋梁近傍に施工寸るとともに，ソフト対策として橋梁
近傍での水位がある值に達した際に列車の運行を規制す る運転規制といわれる方法を古くから行っている ${ }^{12)}$.

増水によって一旦列車の運行が停止された場合には, 増水中に橋梁周りの洗掘深さを明確にとらえることは難 しいため, 水位が低下し運行を再開する際に線路の異常 の有無を主に目視観察によって確認することが多い．ま た，河川水位が通常の水位に低下寸るまで規制解除の時 機を待つことも多く, 安定輸送を確保する観点からは早 期の解除判断が求められている.

一方で，橋脚基礎の健全性を橋脚振動から把握しよう とする研究は古くから実施されており, 列車通過時の振 幅や周期から判定する方法3や橋脚の頂部に衝撃力を与 えた応答波形のスペクトル解析から橋脚の固有振動数を 算出し健全度を判定寸る衝撃振動試験 4 , , などが知られ ている. しかし，これらの方法を増水時に実施すること は作業性・安全性の面あるいは特別な設備を要するなど, 困難な場合が多い。

そこで本論文では，増水中に衝撃振動試験等を行うこ となく, 微動計測によって基礎の健全性を表す指標であ る固有振動数を求めることを目的としている.ここでは, 鉄道において洗掘被害を受けた件数の多い基礎形式のの 
一つである直接基礎形式の橋脚を対象に，橋脚の固有振 動数を求めることを目的として実施した模型実験および 実橋梁における微動計測を通じて，橋脚の固有振動数を 推定するアルゴリズムを提案するものである.

\section{2. 増水による運転規制と維持管理上の課題}

\section{(1) 鉄道によおる増水時の運転規制の変遷}

鉄道には，増水時の橋梁の異常の有無を確認するルー ルが戦前からあり, 古くは出水の規模を量水標によって 判断し記録するように定めていた1)。また，増水時には 橋梁の安定性が損なわれる洗掘などの現象の発生が想定 されるためであり，出水規模と被災経験の蓄積をもとに， 列車の運行を抑止すべき規制水位が設けられてきた。 そ うした中，1968年10月に第一富良野川橋梁脱線事故( ${ }^{6}$ が 発生した. この事故を契機として「予想限界洗掘深さの

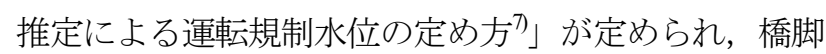
周囲の最大洗掘深をあらかじめ推定した上で水位に関す る運転規制の基準值を定める考え方が初めて具体的に示 された。

さらに1972年9月には「降雨に対する運転規制基準作

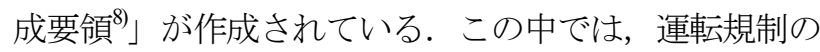
基準となる水位は, 洗掘や河床の変化, 流下物の衝撃に よる構造物への影響および護岸壁や堤防の高さ等を考慮 して定めることとしている.このうち洗掘に対しては， 最大洗掘深を推定した上で，その状態での橋脚の転倒， 滑動，沈下の各々に対する基礎の安定計算を行って定め る.この際，安全率の目安は列車停止に対して1.2, 徐 行に対して 1.5 と定めている.

さらに，1982年8月に発生した東海道本線富士川橋梁 での橋脚が倒壊するという災害を受けて，長期的な河床 の変動を考慮した上で洗掘深の予測を行うことの重要性 が示された9).

このように，いくつかの災害を契機として洗掘と橋脚 基礎の安定性を関連づるように列車の運転規制方法が 改善されてきており，現時点でも基本的には橋脚周りの 水位に応じて運転規制が行われている.

\section{(2) 振動による鉄道橋梁の健全度診断の経緯}

鉄道では，列車密度の増加や輸送量の増大および建設 後30年以上経過した橋梁が大半を占めるようになった頃 から, 平常時における橋脚の健全度を判断する必要が生 じ，躯体の老朽化や基礎部の劣化を橋脚振動から把握し ようとする研究が古くから実施されてきた．そうした中， 梶田ら それらに基づいて1965年に振動による橋梁下部工の健全
度判定指針が定められた.この手法は列車走行時の橋脚 の短周期と長周期の振動波形の形状，その振幅と周期， ならびに列車荷重による橋脚反力の単位荷重に対する橋 脚の沈下量（単位沈下量）から，橋脚の支持地盤の状態 と橋脚身体の健全度を求めようとするものであり，国鉄 時代にはその手法によって健全度診断が実施されてきた。

一方，このような橋脚の振動性状を根入れ深さと直接 的に関連付けることを目的として，岡田らは，鉄道橋脚 のロッキング振動の固有振動数に着目し, 直接基礎 ${ }^{10)}$, 杭基礎 ${ }^{11)}$ とケーソン 基礎 ${ }^{12}$ を有する実物橋梁の振動実験

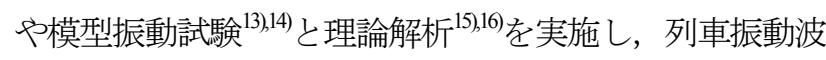
形からの固有振動数の抽出法，根入れ深さの減少が固有 振動数の低下に関係することや，隣接橋脚と上部工が橋 脚振動に及ぼす影響などを定量的に明らかにした。

さらに，西村・棚村 ${ }^{4)}$ は，重錘を用いて橋脚の頭部に 衝撃を与え，応答波形のスペクトル解析から，その構造 物の固有振動数を把握し, 構造物の健全度を調査すると いら衝撃振動試験法を開発した。また，羽矢・稲葉 ${ }^{17)}$ は, 衝撃振動試験から求めた固有振動数から求めた健全度指 標值 $\kappa （$ 実測固有振動数/固有振動数の標準值）によっ て，構造物の健全度のランク（A1，A2，B，S）を判定 することを提案している. この衝撃振動試験法は, 多く の現場で健全度診断や洪水時の安全管理 ${ }^{18}$ に用いられて いる.

また，中村ら $\left.{ }^{19}\right)$ は，橋脚の微動計測から微動に占める 橋脚のロッキング振動成分の割合から寄与率およびR值 を橋脚の健全度指標とする手法を提案した。

\section{(3) 本研究の目的}

列車の安定輸送を確保するため, 上述のような水位に よる運転規制が発令された橋脚に対しては，速やかに基 礎の健全性を評価し，規制解除の可否を判断することが 重要である.しかし，重錘などの特別な設備を要する試 験を増水時において橋梁上で測定することは困難であり， 作業員の安全の確保等の観点からも課題である.

そこで本研究では, 根入れ深さと基礎の安定性との関 係から, 衝撃振動試験による橋脚基礎の健全度指標であ る固有振動数に着目し，増水時の微動からより簡易に橋 脚の固有振動数を求めることを目的としている.

\section{3. 模型実験による増水時の橋脚の微動計測}

河川橋脚では，増水時に基礎部周辺が洗掘されて，そ の振動特性が変化する．そこで，橋脚基礎の支持条件お よび流水条件の変化が橋脚の振動性状に及ぼす影響を定 性的に確認することを目的として，二次元水路を用いた 
水理模型実験を行った.

\section{(1) 模型実験の概要}

実験では，開水路のなかに構築された人工地盤に橋脚 模型を設置し, 地盤条件（地盤強度，根入れ長）や流水 条件（流速，水位）を変化させて, 橋脚天端を水平方向 に打撃する衝撃振動試験と, 微動計測を行った.

\section{a) 模型実験における相似則}

水理模型実験において，流体は実物と同じ水を用い実 物と同じ重力場で実験を行う場合には一般にフルードの 相似則が用いられる。つまり，フルード数が実物と模型 で等しいとすると，相似則は次の関係が成り立つ.

$$
\begin{array}{ll}
\text { 長さ } & \lambda_{\mathrm{L}} \\
\text { 時間 } & \lambda_{\mathrm{T}}=\lambda_{\mathrm{L}}{ }^{12} \\
\text { 流速 } & \lambda_{\mathrm{V}}=\lambda_{\mathrm{L}}{ }^{1 / 2} \\
\text { 質量 } & \lambda_{\mathrm{M}}=\lambda_{\mathrm{L}}{ }^{3} \\
\text { 振動数 } & \lambda_{\mathrm{F}}=\lambda_{\mathrm{L}}{ }^{-12} \\
\text { 地盤ばね } & \lambda_{\mathrm{K}}=\lambda_{\mathrm{L}}{ }^{2}
\end{array}
$$

\section{b) 模型橋脚と模型地盤の作成}

実験で模擬した実物橋脚は，比較的軽い単線橋脚であ り，身区体幅（橋軸方向） $1.5 \mathrm{~m}$ ，高さ $10.4 \mathrm{~m}$ ，質量 $47,000 \mathrm{~kg}$ を対象とした．模型橋脚は形状を単純化して円筒形，材 質はモルタルとし，模型と実物の縮尺比を $1 / 15$ とした場 合, 直径 $0.1 \mathrm{~m}(=1.5 \mathrm{~m} / 15)$, 高さ $0.7 \mathrm{~m}(=10.4 \mathrm{~m} / 15)$, 質量は $12.9 \mathrm{~kg}$ となるが質量を確保するために中心部に鉄筋を挿 入し13.7kgとした。これは相似則から得られる13.9kgに ほぼ一致する。

また，模型地盤は，実地盤における基礎の支持層の $N$ 值を 30 とした場合, 変形係数 $E$ は $E_{0}=25 N^{20)}$ から $75,000 \mathrm{MN} / \mathrm{m}^{2}$ となり, 相似則から模型地盤の変形係数は $333 \mathrm{MN} / \mathrm{m}^{2}\left(=75,000 / 15^{2}\right)$ となる. 一方, 鉄道における橋 脚の固有振動数 $f_{0}$ は，概ね $2120 \mathrm{~Hz}$ の範囲にあること离が 知られているので, 模型橋脚の固有振動数 $f_{0}$ は相似則か ら4 77Hz程度とする必要があり, この固有振動数を目 安に模型地盤を作成した. 模型地盤は, 質量比で豊浦標 準砂8に対し，カオリン粘土2の割合て配合した混合土を 最適含水比 (11.8\%) で締固めて作製した。作製した模 型地盤は三軸試験により変形係数 $E_{50}$ が $20.9 \mathrm{MN} / \mathrm{m}^{2}$ であっ た．なお，実験に用いた加速度計の感度の制約から，想 定される実地盤よりも軟らかい模型地盤を採用せざるを 得なかったが，模型橋脚の固有振動数が概ね相似則に沿 った振動数であることから，根入れの減少にともなう固 有振動数の低下の傾向を定性的に把握する目的は果たせ ると考えた.

\section{c) 水流の条件}

実験では水深の無い状態（水位 $0 \mathrm{~m}$ ) と静水時（水位 $0.3 \mathrm{~m} ）$ および流水時（水位 $0.3 \mathrm{~m} ）$ のケースを実施した.
流速を $0.80 \mathrm{~m} / \mathrm{s}$ （実物換算 $3.0 \mathrm{~m} / \mathrm{s}$ ） とした場合，流水時の 水深 $0.30 \mathrm{~m}$ （実物換算 $4.5 \mathrm{~m}$ ） に対して, フルード数は約 0.47 となる。

なお， 円筒形橋脚に作用寸る主要な加振力には造波抵 抗，橋脚後流域での渦，流れの乱れなどが考えられる. 開水路における縮小模型による水理実験の場合，造波抵 抗により橋脚に作用する抗力の相似性は基本的に満足さ

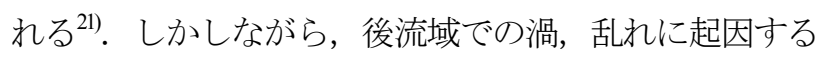
形状抵抗，カルマン渦による揚力の影響については式 (1)に示すストローハル数により規定される.

$$
S t=f \frac{D}{U}
$$

ここに, St : ストローハル数, $f$ : 発生振動数 $(\mathrm{Hz}), D$ : 橋脚の径 $(\mathrm{m}), U:$ 流速 $(\mathrm{m} / \mathrm{s})$ である.レイノルズ数 $(R e)$ が $10^{3}$ を超える範囲であれば円柱のストローハル数は 0.20 である22ので，模型橋脚の径が $0.1 \mathrm{~m}$ ，流速が $0.80 \mathrm{~m} / \mathrm{s}$ とす れば, カルマン渦の発生振動数は $1.7 \mathrm{~Hz}$ となる. 後述す るように模型橋脚の固有振動数 $f_{0}$ は $10 \sim 50 \mathrm{~Hz}$ であり, カ ルマン渦の発生周波数と橋脚の固有振動数とは十分に 離れており, 橋脚の固有振動数 $f_{0} の$ 特定に対してカルマ ン渦の発生振動数は影響しないと判断した.

\section{d) 実験水路と橋脚の設置}

実験に使用した二次元水路は表-1に示すように，水路 幅 $0.8 \mathrm{~m}$, 長さ $20.0 \mathrm{~m}$ である. 水路上流端から約 $11 \mathrm{~m}$ 地点の 水路底部に土槽（幅 $0.400 \mathrm{~m} \times$ 長さ $0.305 \mathrm{~m} \times$ 深さ $0.400 \mathrm{~m}$ ) を設け，ここに地盤材料を敷き詰めて円筒形の橋脚を設 置する．橋脚設置に際しては所定の根入れ長が確保でき, かつ所定の地盤条件が得られるよう, 密度管理を行って 地盤材料を敷き詰めた. 土槽および模型橋脚の設置と加 速度計の配置状況を図-1と図-2に示寸.

なお，土槽の設置位置は上流部で水流を安定させるた めに水路幅の10倍程度を確保し, 下流部で堰による反射 波の影響を最小限に抑えることを考慮して決めた。

\section{e) 橋脚振動の計測}

橋脚振動実験では, 橋脚の微動を計測する他, 橋脚天 端を水平方向にゴムハンマーで軽く打撃する衝撃振動計 測も行った. これらの振動計測には, 橋脚天端に設置し た小型の加速度計（共和電業製AS-1TG）を用いた。 こ の加速度計は, 定格容量 $\pm 1 \mathrm{G}\left(9.807 \mathrm{~m} / \mathrm{s}^{2}\right)$, 応答周波数 範囲 $\mathrm{DC} \sim 40 \mathrm{~Hz}$ （感度偏差 $\pm 5 \% ） ，$ 共振周波数 $70 \mathrm{~Hz}$ ，分 解能 $8.78 \times 10^{-3} \mathrm{~m} / \mathrm{s}^{2}\left(8.953 \times 10^{4} \mathrm{G}\right)$ である.

衝撃振動実験では，30秒の計測時間内に打撃を4回加 え, サンプリング間隔を $1 / 200$ 秒とした。 また, 微動実 験では，計測時間を 180 秒間，サンプリング間隔を $1 / 200$ 秒とした. 


\section{f) 実験ケース}

実験ケースは，水深，流速，橋脚の根入れ長をパラメ 一タとし，振動条件（微動と衝撃振動）別に表-2に示寸 ような10ケースとした. Case1〜Case6までは気中におけ る測定を実施し，Case7は水深はあるが静水中での測定 を，Case8〜10は流水中での実験とした.

\section{(2) 実験結果}

\section{a) 水深がない場合の微動実験による橋脚の卓越振動数}

実験は表-2に示したように根入れを3段階に変化させ, 水深がない条件で実施した，根入れ長が0.1m（Case1）, 0.2m（Case3）と0.3m（Case5）に対する微動実験による フーリエスペクトルを重ねて描いたものを図-3に示す. ここでは，計測された180秒間の微動に対して一括して FFT処理を行いスペクトルを求めている. 図-3によれば, いずれの条件でも $5 \mathrm{~Hz}$ 付近に明瞭な卓越がみられる。こ の5Hzに見られるピークは実験に用いた二次元水路の固 有振動数である.また，Caselでは17Hz付近にピークが みられるものの, 後述する衝撃振動実験による卓越振動 数とは異なっており, この振動数が卓越する理由は不明 である．なお，それ以外の振動数では明瞭なピークがみ られない，したがって，水深がない状態での微動実験か らは，橋脚の固有振動数 $f_{0}$ を特定することができなかっ た.

\section{b) 水深がない場合の衝撃実験による橋脚の卓越振動数}

各根入れ条件における模型橋脚の卓越振動数を特定寸 るために，衝撃振動実験を実施した．実験は水深がない 状態で，表-2に示したように根入れを3段階に変化させ た条件で実施した。根入れ長が $0.1 \mathrm{~m}$ (Case2)， $0.2 \mathrm{~m}$

(Case4) と0.3m（Case6）におけるフーリエスペクトル を重ねて描いたものが図-4である。図-4によれば，いず れの条件でも $5 \mathrm{~Hz}$ 付近に明瞭な卓越が見られる。 また,

Case2では15Hz付近に，Case4では23Hz付近に，Case6では $46 \mathrm{~Hz}$ 付近にそれぞれ明瞭な卓越がみられ，これらが橋 脚の固有振動数である.

\section{c) 水深がある場合の微動実験による橋脚の卓越振動数}

根入れ長 $0.3 \mathrm{~m}$ （Case 7）の静水中における微動試験か ら求められるフーリエスペクトルを図-5に示寸。これに よればいくつかの振動数でピークが見られるものの，橋 脚の固有振動数 $f_{0}$ 付近に明瞭なピークは認められない. また，根入れ長が $0.1 \mathrm{~m}$ (Case8），0.2m（Case9）と0.3m

（Case10）に対する流水中の微動実験によるフーリエス ペクトルを重ねて描いたものを図-6に示寸。これによれ ば5 $\mathrm{Hz}$ 付近と $50 \mathrm{~Hz}$ 近傍に明瞭なピークがみられるが，こ のうち前者は前述のように二次元水路の固有振動数であ り，橋脚の固有振動数 $f_{0}$ は後者に相当する.さらにこれ らの卓越振動数は衝撃振動実験の結果とほぼ一致してい

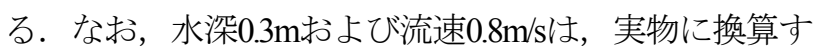

るとそれぞれ $4.5 \mathrm{~m}, 3.1 \mathrm{~m} / \mathrm{s}$ なり，概ね実橋における増 水時の流況とみなすことができる.

以上のことから，限られた流水条件であるが，増水時 に相当する状況下であれば微動から求めた橋脚の卓越振 動数を橋脚の固有振動数として求めることができる可能 性のあることが分かった。

表-1 二次元水路の基本諸元

\begin{tabular}{|l|c|c|r|}
\hline 水路延長 & $20.0 \mathrm{~m}$ & 水路高さ & $1.0 \mathrm{~m}$ \\
\hline 水路幅 & $0.8 \mathrm{~m}$ & 水路勾配 & $1 / 1500$ \\
\hline
\end{tabular}

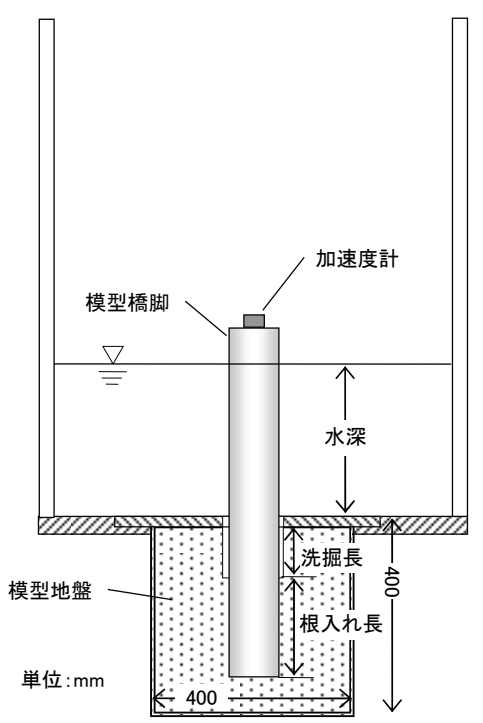

図-1＼cjkstart模型橋脚の設置と加速度計の配置状況

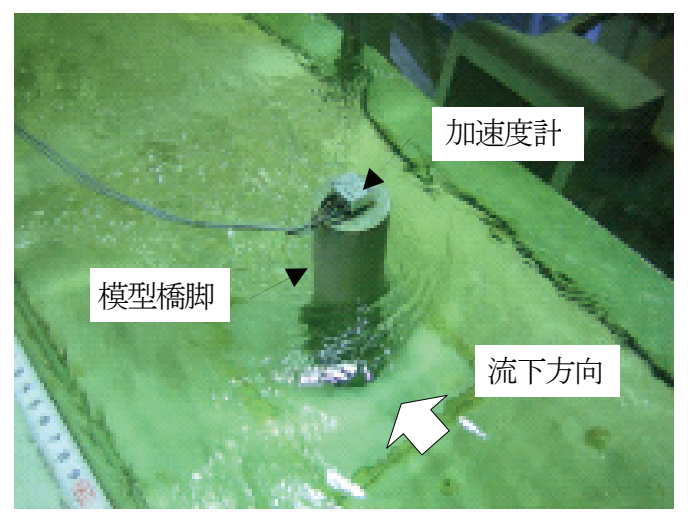

図-2 模型橋脚と加速度計

表-2 実験厅ース

\begin{tabular}{|c|c|c|c|c|c|c|}
\hline case & $\begin{array}{l}\begin{array}{l}\text { 水深 } \\
(\mathrm{m})\end{array} \\
\end{array}$ & $\begin{array}{l}\text { 流速 } \\
(\mathrm{m} / \mathrm{s})\end{array}$ & $\begin{array}{c}\text { 根入れ長 } \\
(\mathrm{m}) \\
\end{array}$ & $\begin{array}{c}\text { 洗掘長 } \\
(\mathrm{m})\end{array}$ & $\begin{array}{l}\text { 微 } \\
\text { 動 }\end{array}$ & 衝 \\
\hline 1 & \multirow{6}{*}{0.0} & & \multirow{2}{*}{0.1} & \multirow{2}{*}{0.2} & 0 & \\
\hline 2 & & & & & & 0 \\
\hline 3 & & & \multirow{2}{*}{0.2} & \multirow{2}{*}{0.1} & 0 & \\
\hline 4 & & & & & & 0 \\
\hline 5 & & & \multirow{2}{*}{0.3} & \multirow{2}{*}{0.0} & 0 & \\
\hline 6 & & & & & & 0 \\
\hline 7 & 0.3 & 0.0 & 0.3 & 0.0 & 0 & \\
\hline 8 & \multirow{3}{*}{0.3} & \multirow{3}{*}{0.8} & 0.1 & 0.2 & 0 & \\
\hline 9 & & & 0.2 & 0.1 & 0 & \\
\hline 10 & & & 0.3 & 0.0 & 0 & \\
\hline
\end{tabular}




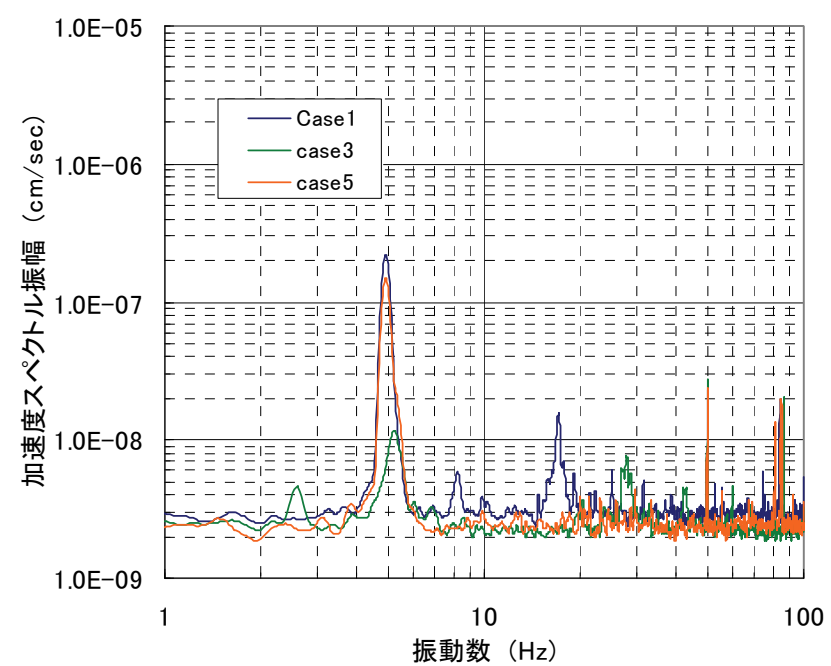

図-3微動実験によるフーリエスペクトル （水深 0m，流下方向成分，Case1，Case3，Case5)

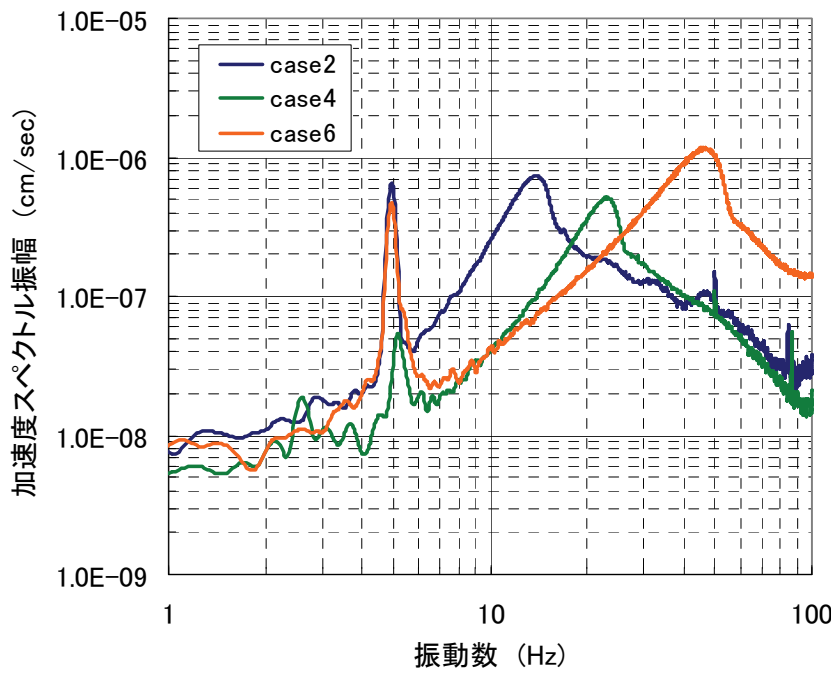

図-4 衝撃振動実験によるフーリエスペクトル （水深 $0 \mathrm{~m}$, 流下方向成分，Case2，Case4，Case6）

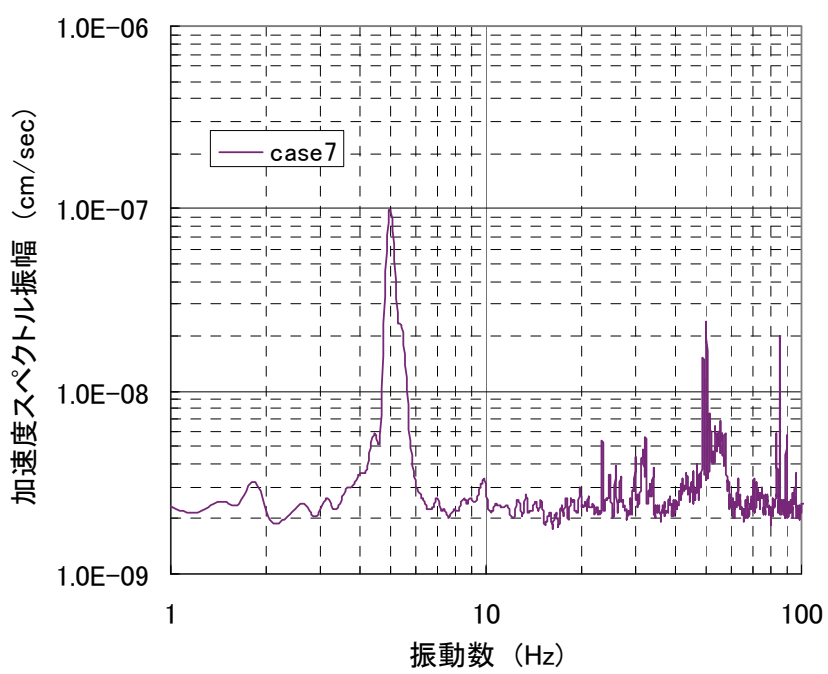

図-5＼cjkstart静水中における微動のフーリエスペクトル (水深 $0.3 \mathrm{~m}$, 流下方向成分, Case 7)

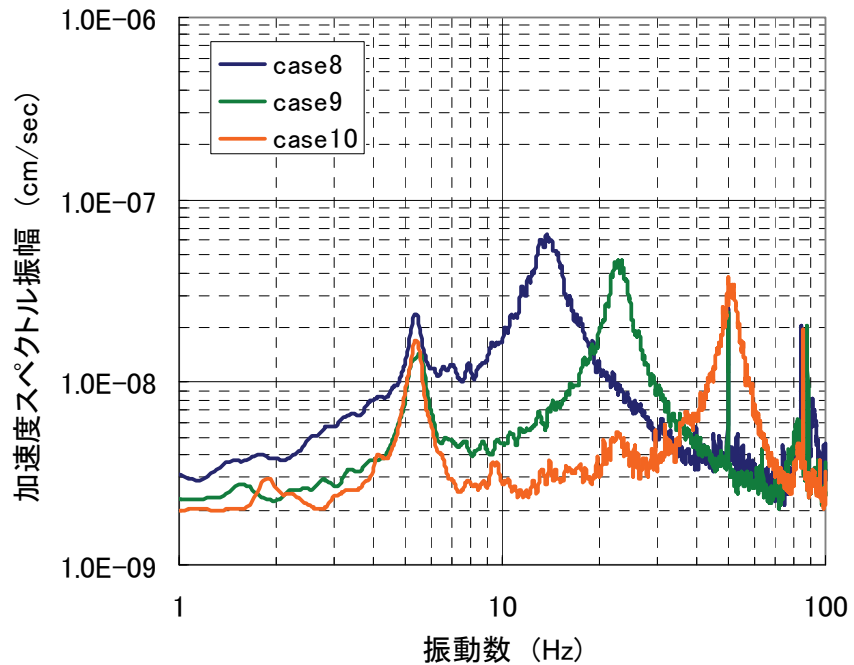

図-6 流水中における微動のフーリエスペクトル （水深 $0.3 \mathrm{~m}$, 流下方向成分, Case8, Case9, Case10)

\section{4. 実橋梁における振動計測}

流水中の模型橋脚の微動から求めた卓越振動数を模型 橋脚の固有振動数とすることができることから，実橋梁 においても同様に固有振動数を得ることができるか確認 する.

\section{(1) 実橋梁における微動計測 a) 計測橋梁の概要}

実橋梁の微動計測は，増水の発生が見込まれる河川の 中流域に位置するA橋梁で実施した.

A橋梁は単線橋梁で，上部工は上路鈑桁（延長 $264 \mathrm{~m}$, 支間10.0 24.0m $\times 14$ 連），下部工は直接基礎形式で断面 が舟形の煉瓦および石造橋脚である，橋梁の一般図を図 -7に, 図-8および表-3に橋脚の諸元を示寸. この橋梁付 近における平水時の流心は，1号橋脚（1P，以下同様） と2Pとの間にある. 橋脚の微動計測は，このうち流心に 近い2Pで行った，なお，計測に先立ち実施した衝撃振動 試験に基づく橋軸直角方向の固有振動数 $f_{01}$ は $11.3 \mathrm{~Hz}$ であ った．なお，橋脚の計測と同様に，隣接する桁および橋 脚の付帯構造物である架線柱についても衝撃振動試験を 実施し，それぞれの固有振動数を特定している.

\section{b) 計測概要}

計測対象とした橋脚天端の上流および下流端に振動セ ンサを設置し，橋脚の微動を計測するとともに，橋脚側 面に設置した水位計によって河川水位を計測した. 図-8 に計測機器の配置の概要を示寸，なお，振動センサは速 度計（物探サービス社製 CR4.5-2S3D）を用いた。この 速度計の周波数特性は $0.5 \mathrm{~Hz} \sim 20 \mathrm{~Hz}$ であり，通常の橋脚 


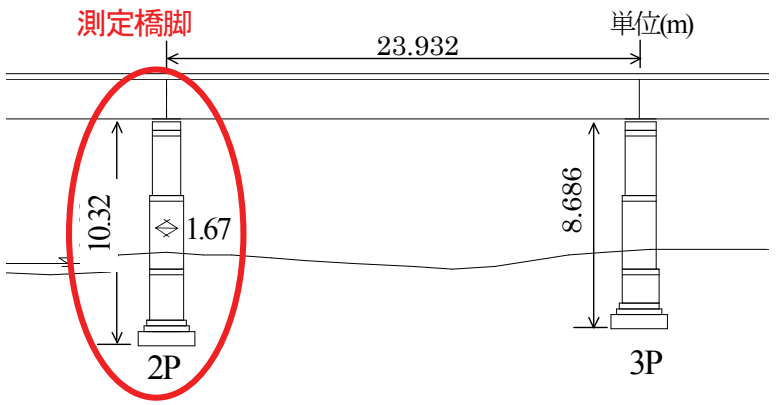

図-7Ａ橋梁の構造一般図

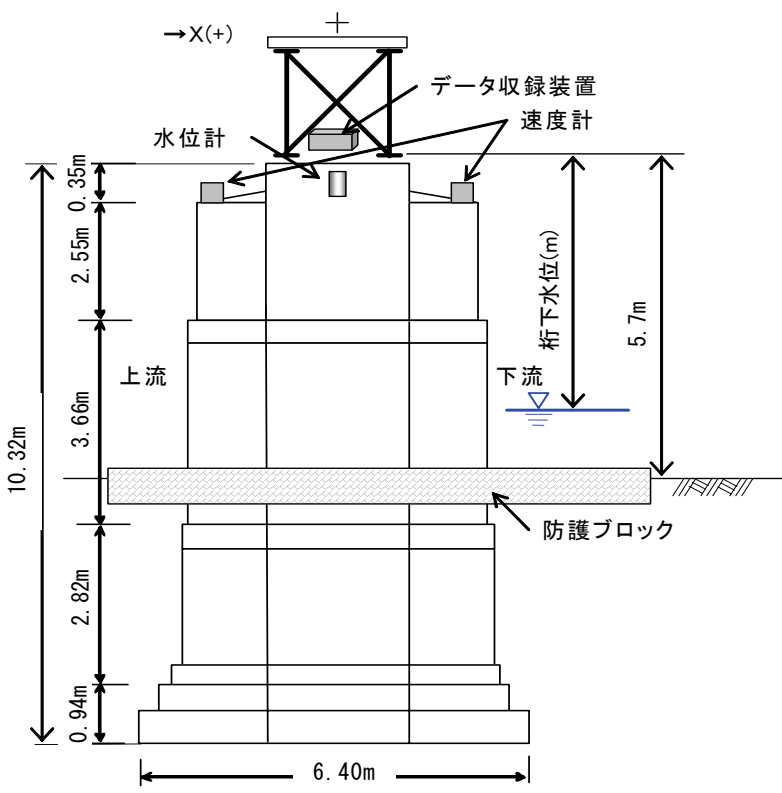

図-8 橋脚の諸元と微動計測の概要図

表-3 計測対象橋脚の諸元

\begin{tabular}{|c|c|c|c|c|c|}
\hline $\begin{array}{c}\text { 橋脚 } \\
\text { 番号 }\end{array}$ & $\begin{array}{c}\text { 橋脚 } \\
\text { 高さ } \\
(\mathrm{m})\end{array}$ & $\begin{array}{c}\text { 橋脚 } \\
\text { 幅 } \\
(\mathrm{m})\end{array}$ & $\begin{array}{c}\text { 橋脚天端 } \\
\text { ＼cjkstart地盤 } \\
(\mathrm{m})\end{array}$ & $\begin{array}{c}\text { 根入れ } \\
\text { 長 } \\
(\mathrm{m})\end{array}$ & $\begin{array}{c}\text { 固有振 } \\
\text { 動数 } \\
(\mathrm{Hz})\end{array}$ \\
\hline $2 \mathrm{P}$ & 10.32 & 1.67 & 5.85 & 4.46 & 11.3 \\
\hline
\end{tabular}

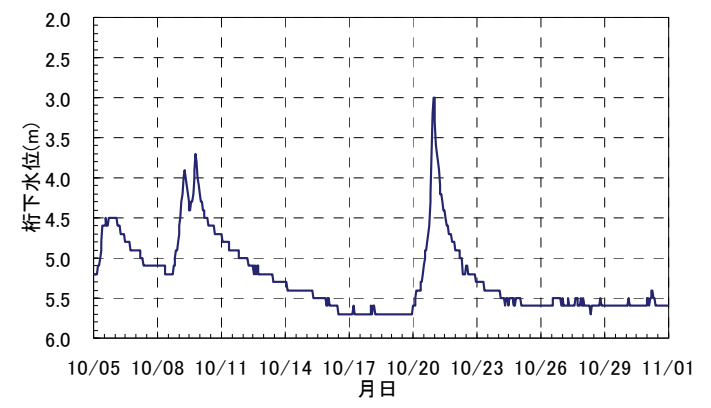

図-9 計測期間中の桁下水位の変化
の固有振動数 $f_{0}$ を包含するものである. センサは，橋軸 直角方向（X方向），橋軸方向（Y方向），鉛直方向（Z 方向）の3成分を同時に測定することが可能であり，橋 軸直角方向の下流方向がX成分の（+）になるように設 置した. 微動計測は毎正時に5分間連続的に行い, サン プリング間隔は1/100秒とした.

\section{(2) 微動計測結果}

a) 平水時と増水時における微動 (速度振幅)の経時変化 計測期間中の河川水位の変化を桁下水位（桁下端部か ら水面までの離隔) で示したのが図-9である．なお，桁 下水位が小さいほど水位が高いことを表している.

$\mathrm{A}$ 橋梁における平水時（桁下水位 $5.7 \mathrm{~m}$ ） と増水時（桁 下水位 $3.0 \mathrm{~m})$ における微動の速度振幅の経時変化を比較 したものを図-10に示す。ここでいう増水時とは，平水 時と比較して約 $2.7 \mathrm{~m}$ の水位上昇がみられたときのもので あり，橋梁の規制水位には達しておらず，増水後の橋脚 および基礎の変状等はみられなかった。 これらの速度振 幅を振幅值の実効值で比較すると，平水時には $1.75 \times$ $10^{-6} \mathrm{~m} / \mathrm{s}$ であったものが，増水時には $8.66 \times 10^{-6} \mathrm{~m} / \mathrm{s}$ と約 5 倍に なっている.

なお，橋脚天端の上流と下流端に設置した振動センサ のデータはほぼ一致しており，橋脚が一体となって挙動 していると判断し，以後は上流端のセンサデータを用い て検討を行う。

\section{b) 平水時と増水時におけるフーリエスペクトルの比較}

平水時と増水時における橋脚の振動性状を比較するた めに，平水時および増水時における上流側橋脚天端での 微動（橋軸直角方向）の速度フーリエスペクトルを図11に示す。また，図には予め衝撃振動試験で得た橋脚の 橋軸直角方向の衝撃振動試験による固有振動数 $f_{0}=11.3 \mathrm{~Hz}$ を緑色の破線で示した。この困によれば，平水時の卓越 振動数は $3.5 \mathrm{~Hz}$ と $7.4 \mathrm{~Hz}$ 付近に見られる. 前者は枌の水平 方向の固有振動数に相当する。，一方，後者は，上路栴の 水平方向の固有振動数の概ね2倍であり ${ }^{23)}$ ，林の鉛直方 向の固有振動数に相当する。これは桁の鉛直方向の動き が橋脚の水平方向成分に現れたものと考えられる. 一方, 増水時では0.3，3.5，4.9，7.3，9.0，11.6，16.9Hzに卓越振 動数が見られる。このうち，3.5Hzと，7.3Hzは，桁の固

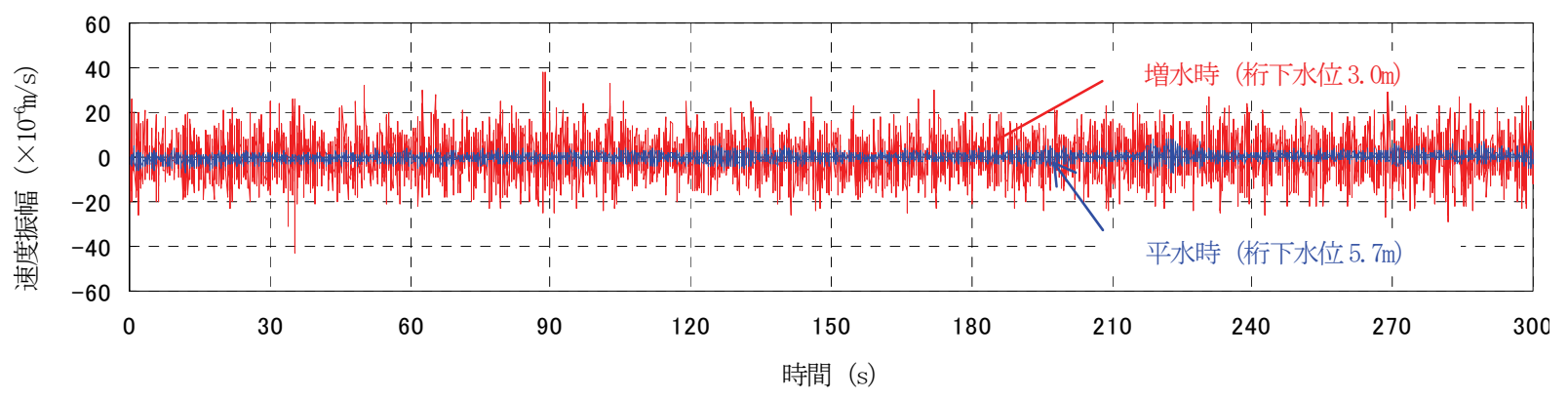

図-10 A 橋梁 2P における微動の速度振幅の時刻歴波形の比較 
有振動数に相当寸るものである. $4.9 \mathrm{~Hz}$ は架線柱の線路 直角方向の固有振動数に相当する．また，11.6Hzは (1) a)で述べた衝撃振動試験による固有振動数 $f_{0}=11.3 \mathrm{~Hz}$ とほ ぼ一致する．なお， $0.3 \mathrm{~Hz}$ は，当該橋脚の周辺における カルマン渦の発生振動数であると考えられる. 舟形断面 をもつ当該橋脚において，ストローハル数は 0.235 , 躯 体幅は1.67mであり，流速は増水時に実測した表面流速 が3m/sであったので, 前述の式(1)より, カルマン渦の発 生振動数 $f$ は $0.42 \mathrm{~Hz}$ となる. この值は増水時の微動によ るフーリエスペクトルの卓越振動数 $0.3 \mathrm{~Hz}$ と概ね近い.

フーリエスペクトルの卓越振動数の時刻的な変化を, 桁下水位の変化とともに描いたものが図-12である. 図12では, 応答の大きい部分を赤く, 応答の小さい部分を 青く表示した.

これによると，10月9日0時から10月10日12時までの間 と10月20日12時から 22 日 0 時までの期間では，水位の上 昇に伴い，11 13Hz, $7 \mathrm{~Hz}, 3.5 \mathrm{~Hz}, 0.5 \mathrm{~Hz}$ 近傍の振幅が大 きくなっていることがわかる．このうち11〜13Hzは前述
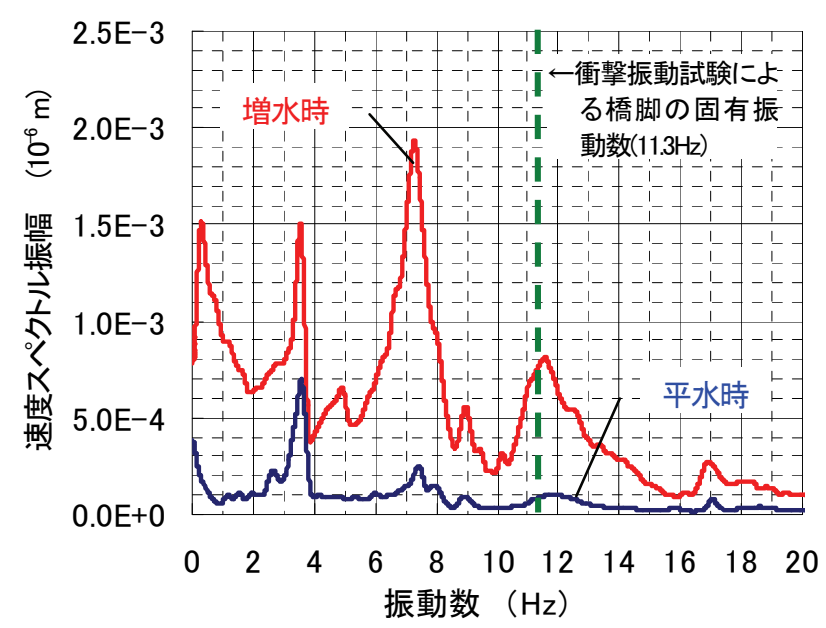

図-11 異なる水位における微動のフーリエスペクトルの 比較
のとおり橋脚の流下方向の固有振動数 $f_{01}$ に該当し, $0.3 \mathrm{~Hz}$ 近傍はカルマン渦の発生振動数と考えられる.

以上のことから, 増水時の流水力によって橋脚が平水 時に比べて大きく振動し, 橋脚の固有振動数 $f_{01}$ に相当す る振動数の速度スペクトルの振幅值が大きくなり, 明瞭 な卓越を示すことが分かった。 したがって, 実橋脚の微 動計測結果から，平水時には困難だが，増水時には橋脚 の固有振動数 $f_{m m}$ をり明瞭に特定できることが分かった.

\section{5. 微動計測による橋脚の固有振動数の特定方法}

上述の4.では，増水時には橋脚の微動から橋脚の固有 振動数 $f_{0 m}$ を捉えられる可能性があることを述べた. ここ では, 橋脚の固有振動数程が既知である場合に, 微動計 測データのフーリエスペクトルの結果から, 卓越振動数 の探索範囲とフーリエスペクトルの解析データ取得時間 に着目して橋脚の固有振動数 $f_{0 m}$ を特定する手法について 述べる.この検討には前述のA橋梁での計測結果を用い る.

\section{(1) 卓越振動数の最適探索範囲の特定}

微動による固有振動数 $f_{0 m}$ は, 次の二つのステップ, す なわち, 第一ステップ; 既知の橋脚の固有振動数 $\left(f_{01}\right)$ を中心として, 測定データの卓越振動数の探索範囲を設 定し，ついで，第二ステップ; 設定した探索範囲内で微 動データのスペクトル振幅が最も大きなピークを示寸振 動数とする，ことによって求めることにした．ここでは， どの程度の探索範囲を設定すれば微動による固有振動数 $f_{0 m}$ を的確に把握できるかが課題となる.

そこで, 最適な探索範囲を特定するために, 既知の固 有振動数 $f_{01}$ と 300 秒間の微動データから解析データ長を 1 ,

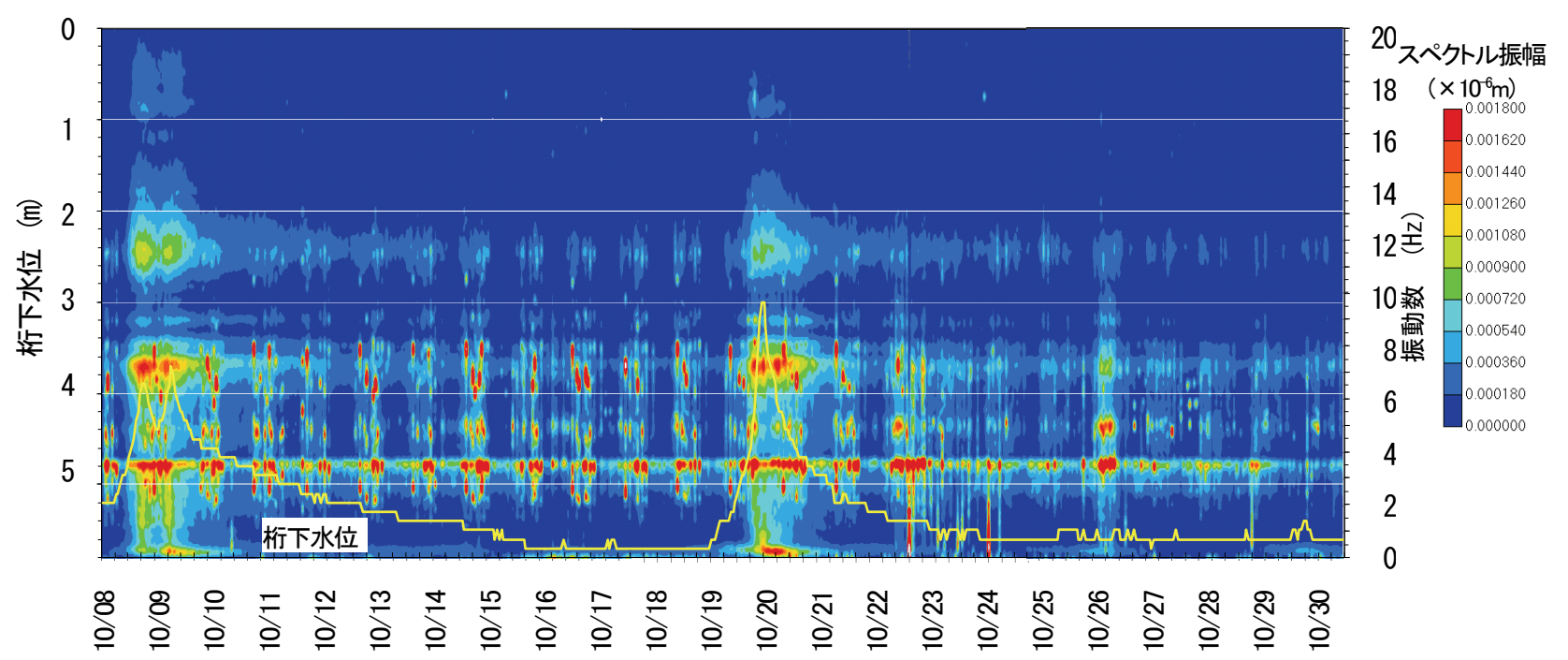

図-12 微動のスペクトル振幅の経時変化 


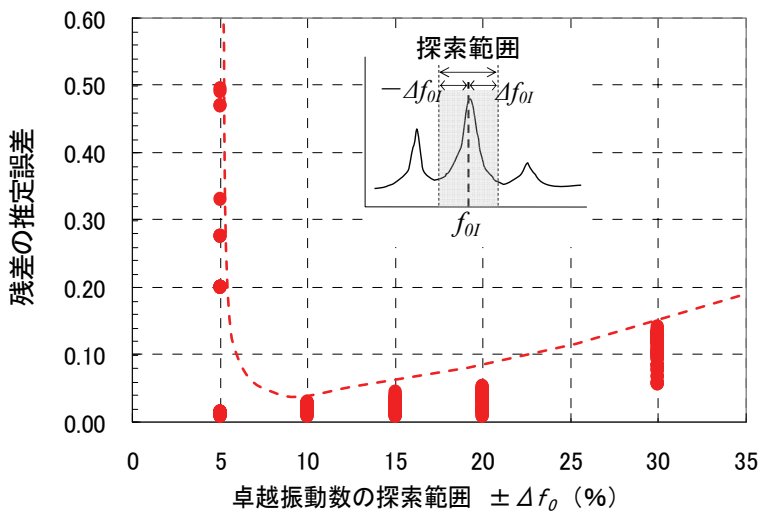

図-13 卓越振動数の探索範囲と固有振動数の残差の推 定誤差との関係

$2,3,5,10,15,20,30,40,50,60,80,100,160$, 200 と 300 秒として計算した $f_{0 m}$ との差の絶対值（以下，残 差という）を求め，それを $f_{0 I}$ で割つた值を残差の推定誤 差として解析した.

増水時（桁下水位 $4.8 \mathrm{~m}$ 以下）の4日分のデータについ て残差の推定誤差と探索範囲との関係を整理したものが 図-13である，図-13は， $f_{0 I}$ を中心にして探索範囲を $f_{0 I} \pm$ $\Delta f_{0}$ としたもので， $\Delta f_{0}$ は $f_{0 I}$ のそれぞれ5，10，15，20と30\% とした。図中の赤波線は，各 $\Delta f_{0}$ における残差の推定誤 差が最大となるデータの包絡線を示す.

この図によれば，探索範囲 $\Delta f_{0} / f_{0 I}$ が $5 \%$ の場合は残差の 推定誤差は0.008～0.495となり，30\%では0.056〜0.14とな る. 一方， $10 \%$ では $0.008 〜 0.029$ と残差の推定誤差の範囲 が5段階の探索範囲のうちで最も小さくなる.このよう な結果を示す理由は，探索範囲が狭い場合には探索範囲 内にピークを特定できず，残差が大きくなり，反対に広 い場合には橋脚の固有振動数 $f_{0 I}$ とは異なる振動数のピー クを特定してしまうためである.このことから，最適探 索範囲を $\Delta f_{0} / f_{0 I}$ が $10 \%$ とすることによって，既知の固有振 動数 $f_{0 I}$ と微動による固有振動数 $f_{0 m}$ の残差の推定誤差のば らつきを少なくすることができる.

\section{(2) データ取得時間長による固有振動数の特定}

上述の(1)では，微動データから卓越振動数の最適探 索範囲の特定方法について述べたが，処理するデータ取 得時間長（以下，解析データ長）によっては微動から求 める固有振動数 $f_{0 m}$ にばらつきが生じる可能性がある.こ のばらつきをできる限り少なくできる解析データ長につ いて検討する.

ここでは，解析データ長を $1 ， 2 ， 3 ， 5 ， 10 ， 15 ， 20$, $30 ， 40 ， 50 ， 60 ， 80 ， 100 ， 160 ， 200$ と300秒の16段階に 設定し，(1)で求めたものと同様に，解析データ長別に 残差の推定誤差を求めた. なお，微動による固有振動数 $f_{0 m}$ を探索する範囲は $\Delta f_{0} / f_{0}=10 \%$ とした。 その結果，解析 データ長ごとに求めた残差の推定誤差とその解析データ

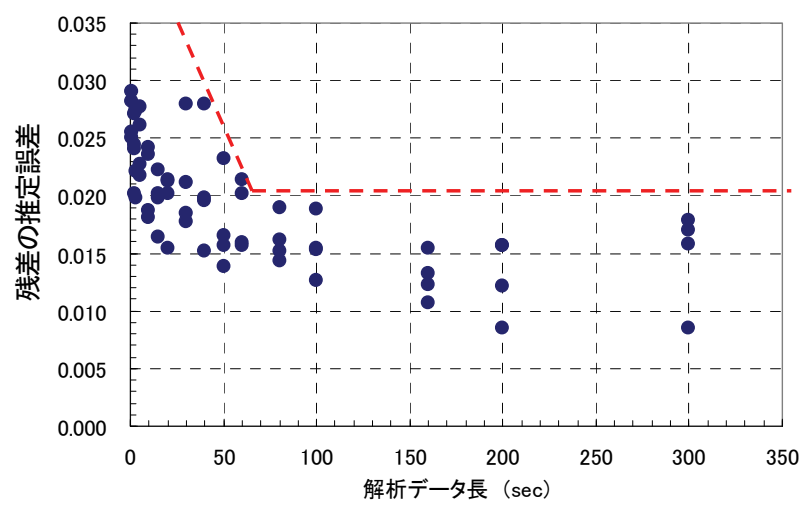

図-14 解析データ長と固有振動数の残差の推定誤差との 関係

長との関係を示したものが図-14である. 困中の赤破線 は各解析データ長における残差の推定誤差が最大となる データの包絡線を示す.

これによれば，解析データ長が 60 秒より短くなると， 残差の推定誤差は急激に大きくなり，それが60秒よりも 大きくなると残差の推定誤差の最大值はほぼ一定の值に なることがわかる．解析データ長が 60 秒以上のデータに ついて残差の推定誤差の平均值 $m$ と標準偏差 $\sigma$ を求める と，それぞれ， $m=0.0145$ との0.0030となる。図-14の赤破 線の60秒以上の範囲では, 残差の推定誤差は全て $\mathrm{m}+1 \sigma$ 以下となっている. 増水時には橋脚基礎の固有振動数 $f_{0 m}$ を可能な限り速やかに評価することが望ましいので，解 析データ長は可能な限り短く設定する必要がある.ここ では，残差の推定誤差がほぼ一定となる60秒を最適解析 データ長とすることが妥当である.

\section{(3) 増水による固有振動数の収束性}

図-12に示したように橋脚の固有振動数 $f_{0 m}$ は，林下水 位の変化によって多少のばらつきを示す。ここでは， 5.(1)と5. (2)で述べた手法から算出した橋脚の固有振動数 $f_{0 m}$ の, 桁下水位の変化に伴う収束性について検討寸る.

図-15は，2004年10月5日0時から同年10月22日23時まで の期間について, 微動から求めた固有振動数 $f_{0 m}$ と桁下水 位との関係を示したものである.困中のH.W.L(High Water Level） は当該橋梁における計画高水位の時の桁下 水位を表し，L.W.L（Low Water Level）は低水位の時の之 れを表す。図-15から，桁下水位が5.7〜 5.1mのときには， 橋脚の固有振動数 $f_{0 m}$ は $f_{0 I} \pm \Delta f_{0}$ の範囲である 10.2 から $12.4 \mathrm{~Hz}$ 範囲内にばらつきをもつて分布しており，その ときの平均值 $m$ および標準偏差 $\sigma$ はそれぞれ $m=11.6$, $\sigma=0.33 \mathrm{~Hz}$ となっている. 一方，水位が上昇し，桁下水位 が $5.0 \mathrm{~m} \sim 4.1 \mathrm{~m}$ となる , 固有振動数 $f_{0 m}$ の平均值 $m$ および 標準偏差 $\sigma$ はぞれぞれ $m=11.6 \mathrm{~Hz}, \sigma=0.27 \mathrm{~Hz}$ ，桁下水位が 4.0〜 3.0m となると, 固有振動数 $f_{0 m}$ の平均值 $m$ および標準 偏差 $\sigma$ はぞれぞれ $m=11.6 \mathrm{~Hz}, \sigma=0.14 \mathrm{~Hz}$ となり，水位の上 


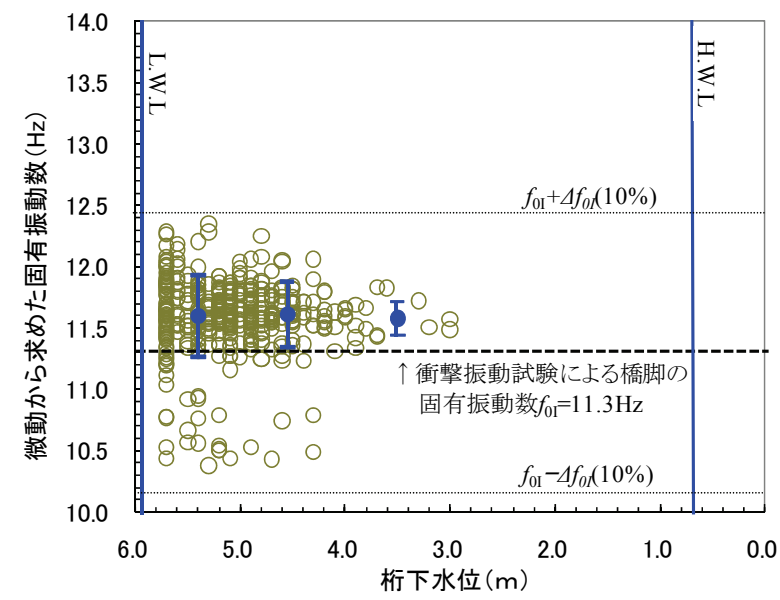

図-15 微動から求めた固有振動数と桁下水位との関係

昇に伴って微動から求めた固有振動数 $f_{0 m}$ が収束していく 様子がわかる. なお，測定期間中は橋脚周辺の地盤条件 に洗掘や土砂の堆積等が発生していないため，水位が低 い場合の固有振動数 $f_{0 m}$ のばらつきは，基礎の状態に関わ らず発生することを示す，一方，水位の上昇にともなっ て橋脚の固有振動数 $f_{0 m}$ は収束する傾向を示寸. これは, 増水による流水力の増加によって橋脚が加振され, 固有 振動数に相当する応答が卓越するためと考えられる.

以上のことから, 増水時においては微動によって橋脚 の固有振動数 $f_{0 m}$ を特定することが可能であることが分か った.

\section{(4) 微動による橋脚の固有振動数の特定アルゴリズム}

上述の(1)から(3)の考察をもとに, 増水時における橋 脚の固有振動数 $f_{0 m}$ を微動から特定するアルゴリズムを図 -16に示す.

このアルゴリズムにおいては, 橋脚の固有振動数 $f_{01}$ が 既知である必要がある。したがって，第一ステップでは, 橋脚の固有振動数 $f_{01}$ が既知であるかの判定を行う. 固有 振動数が未知の場合には，例えば鉄道で用いられている 衝撃振動試験等により決定する.

第二ステップでは, 既知の固有振動数 $f_{01}$ を基淮にして 微動計測に基づく卓越振動数の探索範囲を最適化する必 要がある。最適化には(1)で提案した手法を用いる。探 索範囲が特定できない場合には，固有振動数 $f_{01}$ を心に 固有振動数の $10 \%$ \% $\Delta f_{0}$ として探索範囲を設定する.

第三ステップとして，スペクトル解析に用いるデータ の取得時間長を最適化する必要がある.この最適化には, 上述の(2)の手法に従えばよい。最適なデータ長が不明 の場合には，(2)で提案した60秒間のデータを用いる.

このように新規に卓越振動数の最適探索範囲と最適解 析データ長を求めるためには, 図-16に示寸(A)のフロー を用いるが，この手順を省略する場合には図-16の(B)の フローを適用する.

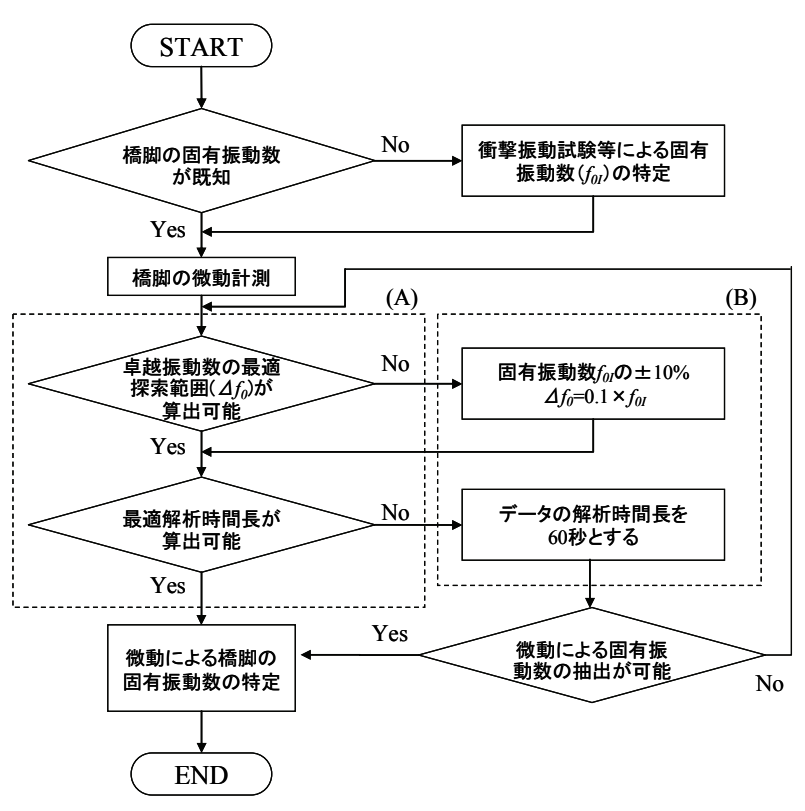

図-16 微動測定から橋脚の固有振動数を特定するアルゴ リズム

この第二ステップの最適探索範囲と第三ステップの最 適解析データ長を用いた図-16のアルゴリズムによって， 増水時の水位変動による橋脚の固有振動数 $f_{0 m}$ の時系列的 な変動を微動計測から追跡できることになった.

\section{(5)特定アルゴリズムの適用条件}

これまで述べてきたように，A橋梁の橋脚では，増水 時の微動によるフーリエスペクトルにおいて固有振動数 に相当する明瞭なピークが見られ，固有振動数の特定が 可能である. 一方, 健全性が高いために橋脚の固有振動 数が高い場合には, 衝撃振動試験においても固有振動数 の特定が困難な場合がある，このような橋脚では，増水 時においても水位の上昇が少なく流水力が小さいため, 微動のスペクトルで橋脚の固有振動数に相当する振動数 が必ずしも卓越しない場合がある。一方，桁や他の付帯 構造物の固有振動数が橋脚の固有振動数と重なってしま い, 両者の分離が困難な場合もまた存在する.このよう な橋脚では, 微動により橋脚の固有振動数を特定する本 アルゴリズムを適用することは困難と考える．

\section{6. アルゴリズムの他橋梁への適用}

上述の5.(4)で提案したアルゴリズムを他の橋梁に適用 し, 橋脚の微動計測から橋脚の固有振動数 $f_{0 m}$ を追跡した 事例を述べる.

\section{(1)適用対象とした橋脚の概要}

提案したアルゴリズムの適用対象としたB橋梁は単線 橋梁で，上部工は上路鈑林（延長 $158 \mathrm{~m}$ ，支間 $18.9 \mathrm{~m} \times 8$ 


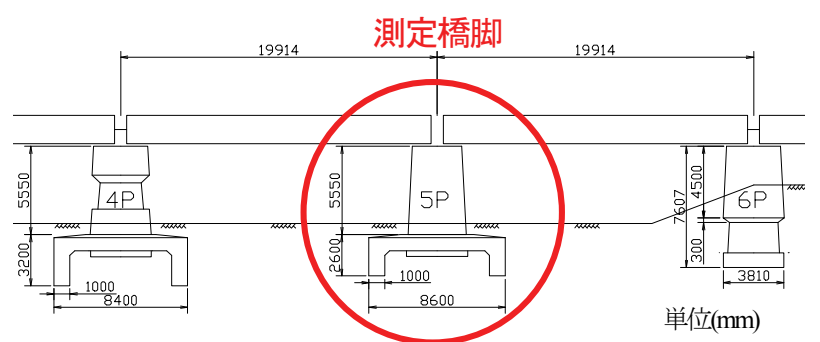

図-17 B 橋梁の構造一般図
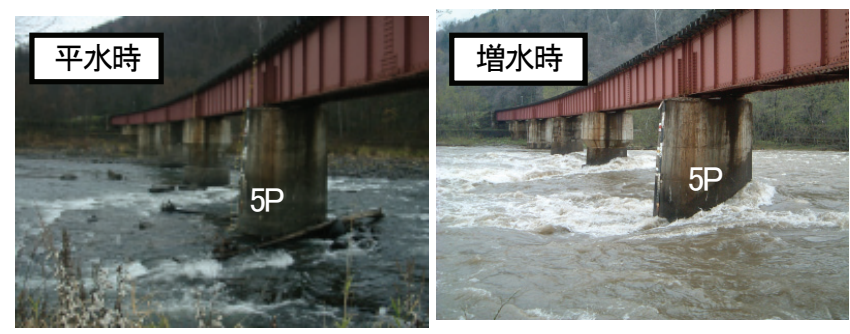

図-18Ｂ橋梁における平水時と増水時の流況

連），下部工は直接基礎形式の円形コンクリート橋脚で あり，橋脚下部には，はかま工が施工されている. B橋 梁の一般図を図-17に示す.この橋梁付近における平水 時の流心は，4Pと5Pとの間にあり，橋脚の振動計測は，

この流心に近い5Pで行った.

計測期間は，2006年8月〜10月である。これによれば， 平水時に実施した衝撃振動試験で得られた5Pの橋軸直角 方向の衝撃試験による固有振動数は $f_{0}=16.8 \mathrm{~Hz}$ である.ま た，桁の水平方向の固有振動数は5連目が $5.4 \mathrm{~Hz}, 6$ 連目 が4.8Hzであった.

\section{(2) 桁下水位の変動}

$\mathrm{B}$ 橋梁における平水時と増水時の流況の比較を図-18 に示す. なお，図に示した平水時の桁下水位は $4.5 \mathrm{~m}$ 程度, 増水時の桁下水位は $3.5 \mathrm{~m}$ 程度である. 当該橋梁における 規制水位は桁下 $1 \mathrm{~m}$ であるため，図に示した増水時には 規制は発令されていない.この橋脚の計測期間中の水位 の時系列変化を図-19に示す.

\section{(3) 微動による固有振動数の特定}

微動による橋脚の固有振動数 $f_{0 m}$ の特定には前述の図一 16のアルゴリズムを，8月18日〜20日までの増水時につ いて適用する.ここでは，図-16に示す(A)と(B)のフロー について検討する.

\section{a)フロー(A)を適用した場合}

前述のアルゴリズムにおいて提案した卓越振動数の探 索範囲 $\Delta f_{0}$ を5.(1)と同様の手法で求めると図-20のように なる.これによれば, $\Delta f_{0} か ゙ 10 \%$ 付近で残差の推定誤差の 範囲が最小值となり，これを最適探索範囲と考えること ができる. また, 解析データ長を, 5.(2)に従って求める と図-21のようになる．図によれば，解析データ長が 60 秒を越えると残差の推定誤差の包絡線はほぼ一定となる ので，60秒を最適解析データ長と設定できる.

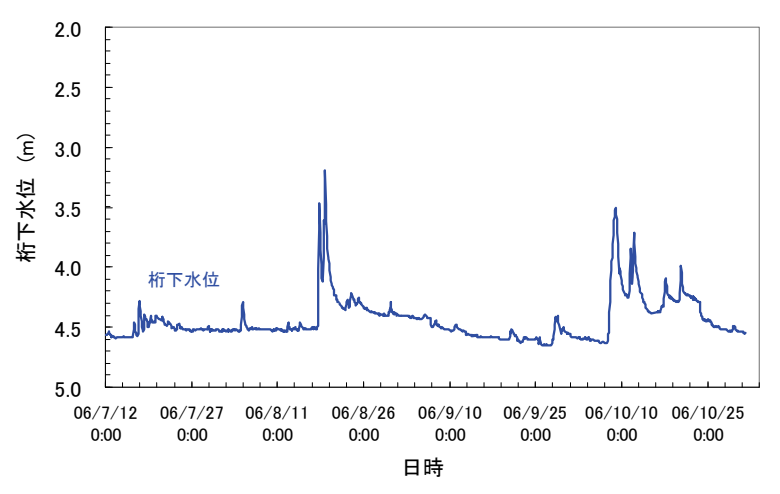

図-19Ｂ橋梁における計測期間中の桁下水位の変化

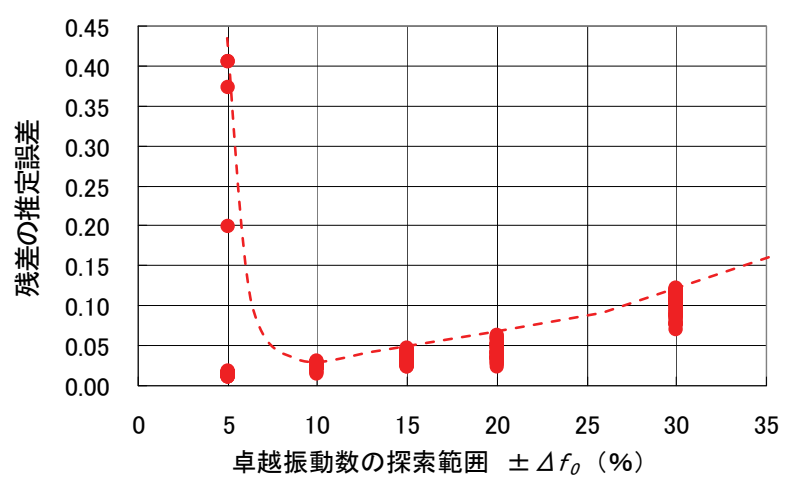

図-20 B 橋梁での卓越振動数の探索範囲と固有振動数 の残差の推定誤差との関係

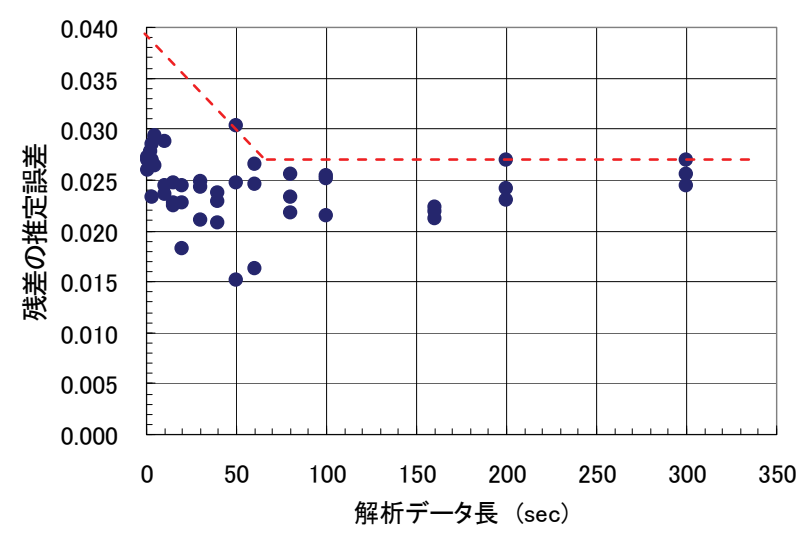

図-21 B 橋梁における解析データ長と固有振動数の残差 の推定誤差との関係

\section{b)フロー(B)を適用した場合}

フロー(B)に従って, 卓越振動数の最適探索範囲 $\Delta f_{0}$ と 最適解析データ長をそれぞれ $10 \%$ と 60 秒と設定して，8 月18日〜20日までの桁下水位が4.0mよりも増水した期間 について, 微動による固有振動数 $f_{0 I} の$ 時系列的な探索を 行った. その結果を図-22に示す. これによれば，微動 による固有振動数 $f_{0 m}$ の平均值 $m$ は $m=16.6 \mathrm{~Hz}$, 標準偏差 $\sigma$ は $\sigma=0.35 \mathrm{~Hz}$ となった。 この平均值 $m$ は，(1)に示した衝撃振 動試験による固有振動数 $f_{0}=16.8 \mathrm{~Hz}$ にほぼ等しい.

したがって，増水時の微動計測データに対してフロー (A)およびフロー(B)の両者を適用して解析した結果，い 


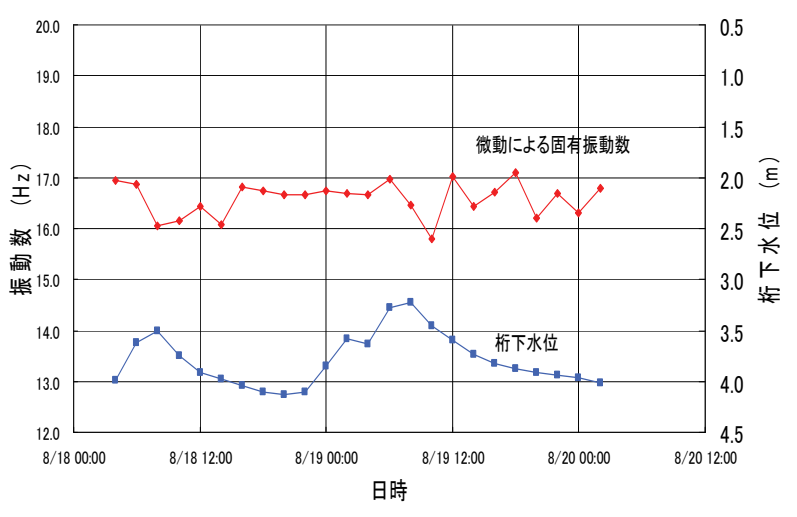

図-22 桁下水位の変化と固有振動数の変化

ずれのフローでも橋脚の固有振動数を特定することがで き，提案したアルゴリズムは妥当な結果を与えるものと 考えられる.

\section{7. 結論}

鉄道において洗掘によって橋脚基礎の安定性が低下す ることが懸念される直接基礎形式の橋脚を対象に，河川 増水時における鉄道橋梁の安定性を評価する上で重要な 指標となる橋脚の固有振動数について, 微動計測から橋 脚の固有振動数 $f_{0 m}$ を特定する手法を提案した. 得られた 結果を以下にまとめる.

(1) 模型橋脚と実橋脚における微動計測によるスペクト ル解析に基づいて，予め橋脚の固有振動数 $f_{0 I}$ が既知であ ることを前提条件として，増水時であれば微動計測結果 から橋脚の固有振動数 $f_{0 m}$ が特定できることが分かった.

(2) 橋脚の固有振動数 $f_{0 m}$ の特定は，微動計測から得られ たスペクトルにおける卓越振動数の探索範囲の最適化と, 解析に用いるデータ長の最適化によって可能となる. そ の特定アルゴリズムを図-16にまとめた.

(3) 最適探索範囲と最適データ長が設定できない場合に は，暫定的な条件として探索範囲を固有振動数 $f_{0 I} の \pm 10 \%$ の範囲とし, 解析データ長を 60 秒に設定して固有振動数 の抽出が可能か娝かを判断する.

(4) 提案したアルゴリズムを他の橋梁に適用した結果, 微動計測のデータから, 橋脚の固有振動数 $f_{0 m}$ を精度良く かつ迅速に特定でき，連続的に微動計測することで時系 列的に追跡できることが分かった.

(5) 増水時に橋脚の固有振動数 $f_{0 I}$ に相当する振動数が卓越 しない橋脚や，橋脚の固有振動数 $f_{0 I}$ 亡桁や他の付帯構造 物の固有振動数が重なる場合には本手法の適用はできな い.

\section{8. あとがき}

本論では，河川増水中の橋脚の微動から橋脚の固有振 動数を求められることを模型実験および実物の橋梁での 計測から示すとともに，橋脚の固有振動数に相当する卓 越振動数を精度良く特定できる方法とそれに基づいたア ルゴリズムを提案し，それを他の鉄道橋梁に適用した事 例を示した. これによって, 鉄道橋脚の固有振動数を迅 速に精度良く，時系列的に特定できることになった。一 方で，本手法が適用できない条件の橋脚への対応や，強 風などの気象条件下での対応が課題として残されている.

今後は, 残された課題の他, 洪水時の橋脚周辺の洗掘 によって生じる根入れ長さの減少に伴う固有振動数の低 下と橋脚基礎の安定性との関係を明らかにし，洪水時の 鉄道橋脚の健全度診断と運転規制方法の改善に努めてい きたい.

\section{参考文献}

1) 鉄道省工務局 : 防災保線読本一風水災編一，1935.12

2) 日本国有鉄道施設局土木課 : 運転規制，警備体制の強化， 1959.11

3) 梶田善, 小林芳正, 川俣淳 : 振動による橋りょう下部構造 物の健全度判定, 鉄道技術研究所報告, No.390(施設編167 号), 1964.1

4) 西村昭彦, 棚村史郎 : 既設橋梁橋脚の健全度判定法に関す る研究，鉄道総研報告，Vol.3，No.8，1989.8

5) 村上 温 : 鉄道橋の洪水時被災機構と安全管理に関する研 究, 鉄道技術研究所報告, No.1307(施設編第573号), p.119, 1986.3

6) 日本国有鉄道施設局 : 国有鉄道線路災害記録（昭和34年～ 昭和 43年度間），1968.7

7) 日本国有鉄道施設局土木課 : 予測限界洗掘深さの推定によ る運転規制水位の定め方， 1968.10

8）日本国有鉄道運転局・施設局 : 降雨に対する運転規制基準 作成要領, 1972.9

9) 日本鉄道施設協会 : 東海道本線富士川橋りょう対策技術委 員会報告書, 1983.12

10) 岡田勝也, 原田康朗, 浅川和夫, 川俣淳 : 直接基礎橋りょ うの正弦加振による動特性と列車走行時の応答性一常磐線 鮫川橋りょう振動試験一，鉄道技術研究所速報，No.81-78， 1981.7

11) 岡田勝也, 川俣淳, 浅川和夫, 原田康朗 : 正弦加振による 橋りょうの動特性と列車走行時の応答性（高崎線神流川橋 りょう振動試験），鉄道技術研究所速報，No.79-84，1979.8

12) 岡田勝也, 原田康朗, 国広敏彦 : 井筒基礎橋梁の正弦加振 による動特性と列車走行時の応答性一重信川橋梁振動試験 一，鉄道技術研究所速報，No.A-85-173，1985.10 
13) 岡田勝也, 原田康朗, 川俣淳, 浅川和夫 : 桁付き橋脚の水 平振動試験（実験編－1），鉄道技術研究所速報，No.78-178， 1978.12

14) 岡田勝也，四十九勇治，原田康朗 : 橋梁の水平振動に及ぼ す根入効果に関する実験，鉄道技術研究所速報，No.A-86130, 1986.6

15) 岡田勝也, 原田康朗 : 多経間橋りょうの水平振動方程式と 模型実験へのその応用一桁付き橋脚の水平振動試験（理論 編）－，鉄道技術研究所速報，No.79-19， 1979.6

16) 岡田勝也, 佐溝昌彦: 橋梁の水平振動に及ぼす根入れ効果 に関する解析，鉄道技術研究所速報，No.A-87-95，1987.3

17) 羽矢洋, 稲葉智明 : 衝撃振動試験における新しい評価基準 值，鉄道総研報告，Vol.16，No.9，2002.9

18) 関雅樹, 田中宏昌，堤要二，山下和敏，中野聡，西村昭 彦 : 鉄道橋の固有振動数に着目した洪水時の安全管理シス
テム，土木学会論文集，No.686/VI-52，pp.78-89， 2001.9

19) 中村豊, 田母神宗幸, 佐藤新二, 立花三裕 : 常時微動を用 いた新しい橋脚健全度評価法の提案，鉄道総研報告，Vol.8， No.5, 1994.5

20) 運輸省鉄道局監修, 鉄道総合技術研究所編 : 鉄道構造物等 設計標準 - 同解説，基礎構造物・抗土圧構造物，SI単位版, p.89, 丸善, 2000 .

21) 椎貝博美 : 水理模型実験法，森北出版，1976.11

22) 本機械工学会編 : 機械工学便覧基礎編A5流体工学, p.100, 1986.4

23) 橋本香一 : 鋼鉄道橋の応力および衝撃に関する研究，鉄道 技術研究所報告, No.713(施設編309号)，p.126，1970.6

(2009.12.10 受付)

\title{
PROPOSAL OF AN ALGORITHM FOR ESTIMATING THE NATURAL FREQUENCY OF RAILWAY BRIDGE PIERS UNDER FLOOD CONDITIONS
}

\author{
Masahiko SAMIZO, Satoshi WATANABE, Akira FUCHIWAKI, \\ Tomoyasu SUGIYAMA and Katsuya OKADA
}

Under flood conditions, a river flow can have a scouring action on a bridge pier foundation, reducing its stability and even toppling it, and as a result causing a severe train accident. In addition to installing protection works and rebuilding deteriorated piers, imposing operational restrictions according to water level is a practical method to secure safe train operations. This paper presents a study on a practical method for evaluating the natural frequency of a bridge pier based on microtremor, in order to support a decision when to lift such res restrictions imposed. In this paper we have proposed an algorithm for estimating the natural frequency accurately and swiftly on the basis of microtremor measurement obtained from a hydraulic model test and existing bridge piers test during high water level. Moreover, the effectiveness of the algorithm has been verified through its application to several different bridge piers. 